\title{
GTZ 대 페루 협력현황
}

\section{1. 사무소 설치 및 인력현황}

- 1975년 사무소 설치, 단독건물(2개 층)을 사 무소로 사용 중

- 사무소 근무인력은 150 명(계약직 포함)

- 전문가 50명(독일에서 파견 15 명, 페루인 20 명, 기타 전문가는 아르헨티나, 칠레, 콜롬비 아 등 주변국 전문가)

- 독일 파견 전문가들은 프로젝트사업 추진

- 행정인력 및 기타 100 명(대부분 현지인)

a 현재 6 개 지역에 분 사무소 운영

\section{2. 추진경위}

- 74년 기술협력협정 체결

\section{3. 사업추진 및 발굴}

- 대 페루 원조전략 수립(2개년 3개년)

- 경제협력개발부, GTZ - 외교부 등 관련 기관 과 협의하여 수립

- 상기 원조전략에 의거, 수요조사 실시
- 페루 국제협력청으로부터 사업요청서 접수 (대사관이 접수)

- 대사관 및 GTZ이 공동으로 일차적으로 사업 요청서 검토

- 대사관, 독일 경제협력개발부에 사업요청서 송부

- 2개년 사업계획 수립

- 경제협력개발부, 외교부 - 대사관 및 GTZ과 협의하여 우수사업 선정

- 타당성조사 실시 및 협의

- 경제협력개발부, 타당성 조사단 파견

- 조사결과에 의거, 양국 정부간 협의 실시(독

일) 및 지원규모 확정

a 협정체결 및 사업추진

- 양국 정부간 2 개년 협력 협정 체결 및 GTZ 사업 시행

- GTZ, 지원분야별로 자국 Consultant를 선 정, Consultant를 통해 사업 실시(분야별 Consultant는 독일에서 선정) 
- 평가

- 양국 정부, 사업시행기관 등이 공동으로 사 업 평가 및 반영

\section{4. 중점 지원분야}

- 민주주의 강화 및 공공행정

- 식수 및 위생

- 농촌개발 및 자원 지속적 활용

- 교육 및 보건

\section{5. 지원규모 및 주요 사업형태}

\section{- 연간 8 10백만 불}

(중남미 지역 제 1 지원 대상국)

- 독일의 대 페루 지원규모 : 연간 약 50백만 불

(무상협력 8-10백만 불, 유상협력 40백만 불)

- 상기 지원 금액 외에 EU를 통해 지원

a 현재 34 개 프로젝트사업 추진 중
- 프로젝트사업 위주로 실시하나 시설 및 기자재 지원 등 인프라 구축 지원은 매우 미미하며 연 수, 국가개발 정책 자문 등 capacity building 에 주력

\section{6. 기타사항}

- 봉사단 파견 : $\mathrm{DED}$ 에서 시행

a 연수생 초청 : InWEnt에서 시행

- 소규모 프로젝트 : 대사관에서 시행

- 차관지원 : $\mathrm{Kfw}$ 에서 시행

- 독일 · 페루 기금 운용

- 페루 정부에 기 제공한 차관 중 일정액을 삭 감, 페루 정부는 삭감액의 $40 \%$ 를 개발 및 빈 곤 퇴치 프로젝트에 투입.

[자료: 주페루 대사관] 